\title{
Histories
}

\section{History of Epidemics in China}

\section{Some Reflections on the Role of Animals}

\author{
Di Lu | ORCID: 0000-0002-0994-2665 \\ Zvi Yavetz School of Historical Studies, Tel Aviv University, Tel Aviv, Israel \\ ludi@tauex.tau.ac.il
}

\begin{abstract}
The global pandemic of COVID-19 as a zoonotic disease invites new reflections on the human-animal relationship in the history of epidemics. Historians have explored medical concepts, social impacts, and other aspects of epidemics in China at different geographical and temporal scales. Relevant research significantly enriches historical understanding, yet animals seldom occupy the center of attention despite the fact that a variety of human infectious diseases such as plague are zoonotic in origin. This article suggests the need for a reappraisal of epidemics in Chinese history, with particular consideration of historical information on the multifold involvement of animals in human infections and anticontagious measures. Rethinking historically the interactions between humans and animals within the epidemic context helps to raise our awareness that Chinese medical thinkers were sensitive to the possibility of zoonotic infection, and prompt new analyses of how they understood the human-animal boundary and beyond.
\end{abstract}

\section{Keywords}

epidemic - COVID-19 - medical history - Chinese medicine - zoonosis 
Over the past century some scholars, such as Imura Kōzen, Li Wenbo, Zhang Zhibin, and Gong Shengsheng, have combed a large quantity of Chinese historical sources for information about epidemic outbreaks. ${ }^{1}$ The latest largescale statistical analysis by Gong Shengsheng and his collaborators reveals that there were 880 epidemic years in the territory of present-day China from 220 BCE to CE 1949. The periods when epidemics occurred at a relatively high frequency ranged from the third to the sixth centuries, and from the eleventh to the mid-twentieth centuries. In particular, epidemics broke out almost annually during the period from the mid-fifteenth to the mid-twentieth centuries. And epidemic years in the southeastern region significantly exceeded that in the central or northwestern region, especially in the last three centuries. ${ }^{2}$ This quantitative characterization provides new and important historical insights. But noteworthily, due to issues related to territorial changes and textual recording and preservation, the varied richness of extant relevant records in different regions and periods does not exactly mirror the actual geographical and chronological features of the epidemics rampant throughout Chinese history. Moreover, the complex interplay of medical, environmental, organizational, cultural, political, and economic factors underlying these abstract numbers can hardly be elaborated through quantitative historical approaches.

\section{Histories of Disease}

Within a broad historiographical framework, Marta Hanson identifies the "naturalist-realist" and "historical-conceptual" approaches to the history of disease. The former treats past disease experience on the basis of present understanding; while the latter situates disease concepts within their historical contexts. ${ }^{3}$ The two approaches, often blended together, are common in recent monographic studies in the history of epidemics in China from chronological, thematic, and geographical perspectives. Zhang Jianguang and Deng Tietao provide two general histories of infectious diseases and anticontagious measures. ${ }^{4}$ Both reveal a naturalist-realist inclination. Other authors have explored medical knowledge, transmission, social influence, and state control of infectious diseases in Jiangnan (a region south of the Yangtze River), Lingnan (the region south of the Nanling Mountains), and other regions in the imperial,

\footnotetext{
1 Imura 1936-37, 263-75, 316-25, 366-76, 414-22, 459-67, 505-7, 550-55, 30-39; Li 2004; Zhang 2007; Gong 2019.

2 Gong, Xie, and Chen 2020, 719-22. Cf. Gong 2003, 870-78.

3 Hanson, forthcoming.

4 Zhang 1998; Deng 2006.
} 
republican, and early communist periods. They more or less take notice of the importance of a historicized and contextualized understanding of disease concepts. Meanwhile, the difficulties in interpreting Chinese disease concepts from a biomedical perspective have to some extent caused the recent increasing emphasis on the social aspects of epidemics in Chinese history. Lai Wen and Li Yongchen trace the temporal-spatial changes in epidemic outbreaks and related social responses in Lingnan from the end of the Tang dynasty to the end of the Qing dynasty. ${ }^{5}$ Yu Xinzhong pays attention to Jiangnan and other regions, offering social studies of public health and the prevention and treatment of local epidemics. ${ }^{6}$ Han Yi does not focus on specific regions but concentrates on the period of the Song dynasty, probing how epidemics were understood by different communities and individuals and treated in different contexts and at national, regional, and other levels. ${ }^{7}$ With respect to epidemics in Republican China, Zhang Taishan's research places emphasis on different social reactions and the shaping of public health. ${ }^{8}$ John R. Watt considers epidemics in the context of medical reforms in wartime China (1928-45), pointing to their stimulating effect on the construction of modern healthcare systems. ${ }^{9}$ Li Honghe, on the other hand, turns to the social impact of epidemics in the first decade of the People's Republic of China, highlighting the positive role of government in epidemic control. ${ }^{10}$

In view of specific categories of epidemics, Zhou Qiong probes into a group of diverse infective agents named "miasmatic qi" (zhangqi 瘴氣) and their roles in social evolution, environmental exploitation, and ethnic stigmatization in Yunnan in the Qing dynasty."11 Angela Ki Che Leung offers a meticulous survey of leprosy in China from the last centuries BCE to the twentieth century, correlating leprosy, lepers, and medical treatment with sociopolitical transformations. ${ }^{12}$ Marta Hanson traces the dynamic concepts of "warm (infectious) diseases" (wenbing 溫病) back over two thousand years, with particular concerns about geographical imagination and regional differences. ${ }^{13}$ The prevalence of plague and its intersection with social stability, state power, and hygienic modernity in late imperial and modern Chinese society has also received much attention from scholars like Carol Benedict, Iijima Wataru, Jiao

\footnotetext{
Lai and Li 2004.

Yu 2003, 2016.

Han 2015 .

Zhang 2008.

Watt 2013 .

Li 2007.

Zhou 2007.

Leung 2009.

Hanson 2011.
} 
Runming, and Cao Shuji and Li Yushang. ${ }^{14}$ These representative studies, informative and inspirational, substantially deepen our historical understanding of epidemics themselves as well as biopolitics, intellectual exchange, and power relations. However, they all center on humans, neglecting or marginalizing the relationship between humans and animals except in a few cases of schistosomiasis and the like. ${ }^{15}$

\section{Animals and Disease}

The global Covid-19 pandemic provokes historical reflection on the role of animals in human infectious diseases. According to John S. Mackenzie and David Williams, "More than $6 \circ \%$ of human infectious diseases are caused by pathogens shared with wild or domestic animals, and over $75 \%$ of emerging diseases are zoonotic in origin." 16 In addition to more than 150 zoonoses caused by certain bacteria, viruses, parasites, fungi, and prions, there are also dozens of reverse zoonoses. ${ }^{17}$ Such contemporary biomedical information does not rationalize a positivist history of epidemics, but it suggests a reappraisal of many medical records that usually fall within the remit of the history of veterinary and livestock husbandry. ${ }^{18}$ Jared Diamond stresses that smallpox, flu, plague, and some other infectious diseases which became the major killers of human beings actually evolved from animal diseases, in concert with the rise of agriculture. ${ }^{19}$ COVID-19 as a new zoonotic disease prompts medical historians to take an interdisciplinary approach, and to treat with caution the epidemics which were generally termed, for example, $y i$ 疫 (epidemics) but in some cases might have zoonotic origins. ${ }^{20}$ This thereby invites more consideration of potential etiological factors and human-animal interaction in the history of epidemics.

It is necessary to be aware of the loose boundaries between humans and animals in premodern Chinese conceptions of the world. ${ }^{21}$ The old text Classic of Mountains and Seas (Shanhai jing 山海經, c. fourth century вCE) describes

\footnotetext{
14 Benedict 1996; Iijima 20oo; Jiao 2011; Cao and Li 2006.

15 Gross 2016; Zhou 2020, 72-101.

16 Mackenzie and Williams 2020, 3.

17 Colville and Berryhill 2007, 3; Messenger, Barnes, and Gray 2014, e89o55.

18 Wang 1958, 107-16; Xie 1985, 90-91; Zou et al. 1994, 247-62; Nong and Chen 1996, 96-100; Han 2015, 280-373.

19 Diamond 1999, 195-214.

20 See Joshua Capitanio's study of yi in Buddhist writings in this issue (Capitanio 2021).

21 For the relationship between humans and animals in early China, see Sterckx 2002, $123-63$.
} 
a number of strange creatures such as a bird with a human face and a beast with horse's hooves and human hands. ${ }^{22}$ The Book of Master Zhuang (Zhuangzi 莊子, c. fourth century BCE) contends that horses can produce humans. ${ }^{23}$ According to Sima Qian 司馬遷 (145 BCE to c. 86 BCE), a woman swallowed an egg dropped by a black bird, and then gave birth to Qi 契, the progenitor of the Shang people. ${ }^{24}$

The obscure human-animal distinction created some common ground between understandings of human and animal physiologies and diseases. The Divine Husbandman's Classic of Materia Medica (Shennong bencao jing 神農本 草經, c. first century вСЕ) and other similar works of later periods, which are usually taken for granted as herbals for merely humans, actually include some veterinary information (e.g., bovine diseases), as did much of the recipe literature recovered in manuscript texts. ${ }^{25}$ Perhaps more intriguingly, the physician Zhang Ji 張機 (c. 150-219) claimed that the meat of the cattle which had eaten snakes could kill persons. ${ }^{26}$ Chao Yuanfang 巢元方 of the Sui dynasty (581-619) further explained that cattle that had mistakenly eaten venomous snakes or grass stained with snake venom would die; its meat then also became "poisonous" ( $d u$ 毒) to humans. ${ }^{27} \mathrm{He}$ described a transfer of poison from venomous snakes to cattle and then human eaters in the food chain; and the human body was basically as sensitive to snake venom as cattle were, despite being affected in an indirect way. Extending the theme of veterinary medicine, a ninth-century treatise on equine medicine enumerates over seventy acupoints in the horse and related acutherapies. The acutherapies often involved puncturing one or more needles into certain acupoint(s) in order to let blood. ${ }^{28}$

\section{Animal $D u$}

Infectious diseases were often associated with diet and the concept of $d u$ (poison/poisonous, etc.), and while not a primary focus, they were also considered to be transferrable between animals and humans. ${ }^{29}$ Of the food prohibitions listed by Zhang Ji in the third century, one was eating cattle which died of

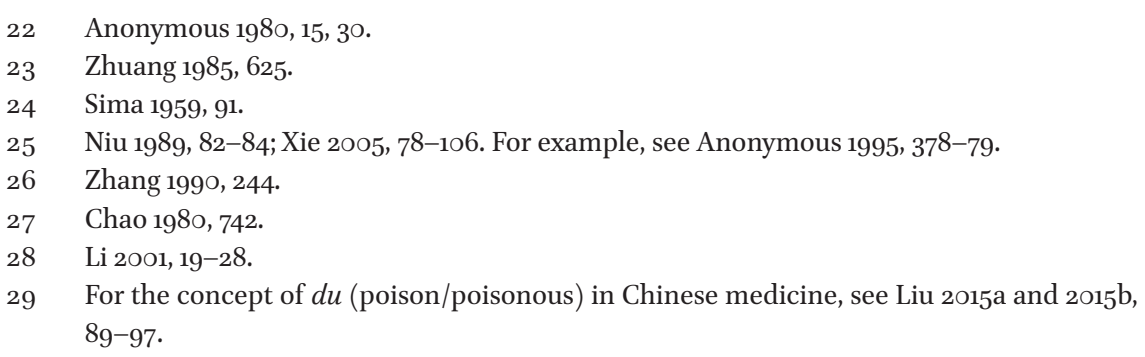


infectious diseases, whose eyes turned red or yellow. Furthermore, the flesh of cattle which died of infectious diseases could sicken the eater, causing diarrhea or indigestion; livestock which died this way were considered poisonous and thus inedible. ${ }^{30}$ Chao Yuanfang also warned about the toxicity of the flesh of animals killed by infectious diseases. ${ }^{31}$ Both Zhang and Chao implied the transmissibility of certain infectious poison from animals to humans through diet. The Daoist physician Ge Hong 葛洪 (283-343) used the term "warm (plague) poison" (wendu 溫毒) or “plague poison” (yidu 疫毒) to describe the toxicity of epidemics to humans; despite no mention of animals, Ge is among the earliest to articulate an explicit theory of intrahuman disease transmission. ${ }^{32}$ The notion of plague poison later circulated among wide audiences, and was sometimes considered to materialize as "smallpox" (dou 痘), as reported in the Essential Discourses on Investigating Things Regarding Smallpox (Douzhen gezhi yaolun 痘疹格致要論) by the Ming physician Wan Quan 萬全. ${ }^{33}$ Plague poison also appeared in the well-known treatises on human epidemics by Wu Youxing 吳有性 (1582-1652) and Dai Tianzhang 戴天章 (1644-1722). ${ }^{34} \mathrm{Wu}$ alleged that an internal structure named the "membrane area" (moyuan 膜原) was where plague poison from outside first incubated in the human body. ${ }^{35} \mathrm{In}$ the eighteenth century, an imperial medical text explained Zhang Ji's thinking about livestock which died from infectious diseases as follows: the plague poison could kill livestock, so the meat of such livestock must have plague poison and thereby could not be eaten. ${ }^{36}$ To be sure, such an assertion seems to aim at the health of individuals and dietetic hygiene rather than large-scale epidemic prevention. But clearly it illustrates a chain of infection that directly links animals with humans.

\section{Plagues as a Category of Animal Husbandry}

Epidemics of humans and livestock (renchu juyi 人畜俱疫) were often mentioned in the context of astro-divination. ${ }^{37}$ While such divination often is not

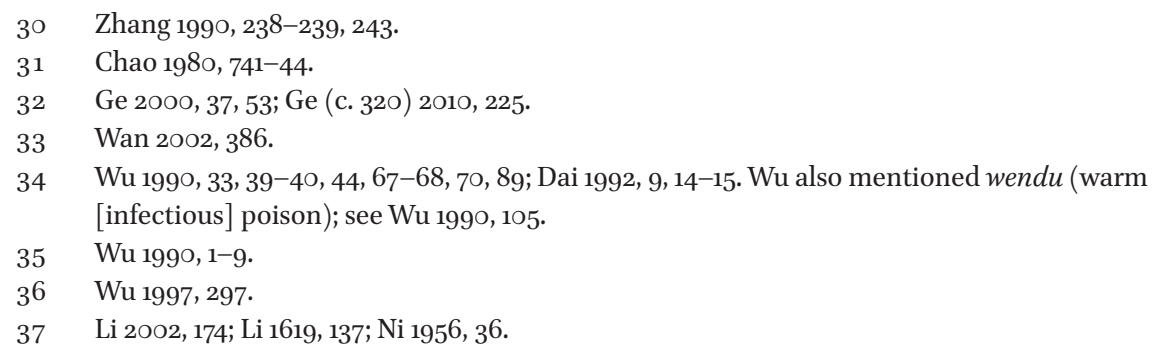


taken seriously today, it may have been derived from empirical observation of historical events. Due to their important role in human life, livestock and their health and illnesses raised concerns of not only diviners but also physicians, historians, and literati. Cattle epidemics are mentioned a number of times in the History of the Latter Han Dynasty (Houhan shu 後漢書), and a Tang dynasty text excavated in Turfan records a recipe for cattle epidemic. ${ }^{38} \mathrm{~A}$ tenth-century physician recommended using black beans to remove plague poison in cattle and horses. ${ }^{39}$ This method may have roots in early apotropaic rites which used beans against plague demons. ${ }^{40}$

The import of historical records of epidemics that sickened and/or killed both humans and livestock was by no means confined to astro-divination. A Ming dynasty prescription text describes how many butchers and others who cut up and thereby touched (sick and) dying horses and donkeys were themselves killed by the poisonous qi from the animals. ${ }^{41}$ Some scholars have treated this and some other accounts as evidence of anthrax infection. ${ }^{42}$ Elsewhere, Shen Defu 沈德符 $(1578-1642)$ once noted that in 1502 lots of humans and livestock died of epidemics in Jingdong, Yunnan. ${ }^{43}$ At least some of such records may suggest the possibility of zoonotic epidemics. In the spring of 1894, Jin Wuxiang 金武祥 witnessed the ravage of "rat plague" (shuyi 鼠疫) in eastern Guangdong. He interpreted the deaths of many rats and around ten thousand people in the following way: the plague ( $y i$ 疫) emerged from earth qi (diqi 地氣), and thus first struck rats in underground caves; local inhabitants came across the plague qi from the infected rats, and then fell ill and died. ${ }^{44}$ Medical historians have confirmed the outbreak of plague in Guangzhou and neighboring areas in 1894, which roughly preluded the third bubonic plague pandemic. ${ }^{45}$

Jin's interpretation of the etiology of plague reflects the influence of indigenous intellectual traditions. Of course, understandings of epidemics in Chinese society had never been homogenous. In the late Ming dynasty, $\mathrm{Wu}$ Youxing attributed the emergence of epidemics among humans, cattle, goats, chicken, and so forth to the invisible "miscellaneous qi" (zaqi 雜氣) from the ground, stating that such infectious qi could not shift across species (e.g., from

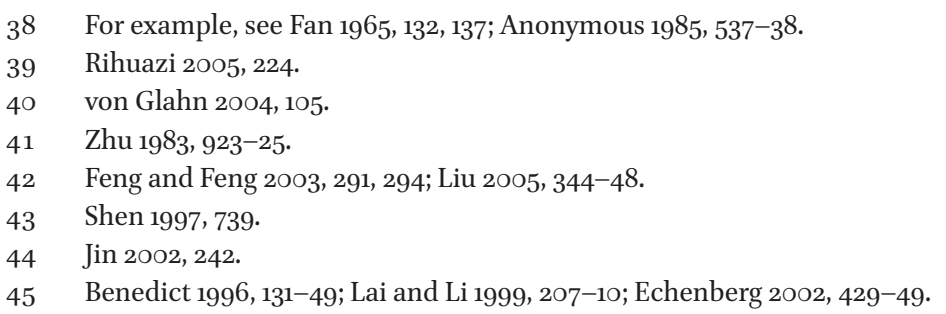


cattle to goats, or from humans to livestock). ${ }^{46}$ Nevertheless, Zhang Zongfa 張 宗法 (fl. eighteenth century) saw fit to cite a record in his agricultural work, Annals of the Three Farmers (SannongJi 三農紀), which discussed interspecies disease transmission, while not stretching as far as a zoonotic theory (the theory that animals can communicate disease to humans). It argues that human plague affects humans, and livestock plague affects livestock, because plague spreads among living beings that are similar in appearance. Further, probably because in the eyes of the author, living beings within the category of livestock are similar, swine plague can spread to cattle, and vice versa. ${ }^{47}$

\section{Animal Flesh: Prophylactic, Portent, or Precipitant}

In addition to the above scattered references to mentions of either animal plague or possible zoonotic infection, we also see theories of animal flesh being used as a prophylactic against, a portent of, or a precipitant of epidemic disease. The mystical geographical work Classic of Mountains and Seas recounts a variety of early Chinese legends and animals, plants and minerals in different regions. In terms of the eastern mountains (dongshan 東山), those who ate a local fish called zhenyu 筬魚 (possibly a Japanese halfbeak, or needlefish, Hyporhamphus sajori) could thus avoid epidemics. When a bird called jiegou 絜銁 appeared in a given country, it mostly portended the forthcoming of epidemics. ${ }^{48}$ In medieval times, otter meat was considered suitable to treat both human and equine epidemics. The sixth-century agronomist Jia Sixie 賈思諰 instructs readers in Essential Techniques for the Welfare of the People (Qimin yaoshu 齊民要術), a mixed text of agricultural techniques, culinary recipes, and general advice for farm management, that they should boil otter excrement and then feed it to infected cattle and horses; otter excrement is recommended when one cannot obtain otter meat and liver which are actually more effective. ${ }^{49}$

The physician Sun Simiao 孫思邀 (d. 682), discusses otter meat in his encore magnum opus, the Supplementary Prescriptions Worth a Thousand in Gold (Qianjin yifang 千金翼方), in a section on the medicinal properties of different drugs. Here he states that otter meat can treat plague qi and warm (infectious) diseases. ${ }^{50}$ By contrast, where otter flesh was considered a cure, beef was

\footnotetext{
$46 \quad$ Wu 1990, $5^{8-59 .}$

47 Zhang 1989,585 .

48 Anonymous 1980, 102, 110.

49 Jia 1982, 286.

50 Sun $1998,62$.
} 
considered by some to attract infectious diseases when consumed on ritually significant days. In his work on folk customs relating to special days or periods of a year, the thirteenth-century author Chen Yuanjing 陳元靚 noted a belief that families who did not eat beef on the fifth day of the fifth lunar month would not be visited by "plague spirits" (wenshen 瘟神). ${ }^{51}$ The fifth of the fifth, known commonly as the festival of Duanwu 端午, occurs at the height of summer, and was widely considered to be a dangerous time when humans and crops were particularly subject to the influence of spirits, vermin, insects, and plagues, and apotropaic recipes, talismans, rites, and decorations were widely used. The prohibition on beef at this period drew from an old antipathy toward meat generally in religious rites expressed in an emergingly wide new focus on beef in the Song-Yuan period. ${ }^{52}$

Within more focused medical literature the renowned herbalist Li Shizhen 李時珍 (1518-93) recorded in his monumental work, the Compendium of Materia Medica (Bencao gangmu 本草綱目) that eating salted and dried rooster meat at the beginning of spring could prevent human epidemics (piyi 辟疫). In a more ritual vein, burying a rat in one's residence on the first day of the first lunar month could also prevent the same. ${ }^{53}$ These aside, Li was also aware of the potential for wild animals to cause disease to humans, and argued against wild foods. ${ }^{54}$ Repeatedly in his description of wild animals, whether peacocks, crows, geese, mallards, mandarin ducks, rhinoceroses, wild horses, bears, otters, snakes, pangolins, and more, he methodically portrays specific fevers, aches, rashes, boils, and other ailments that they can produce. These latter were conceived from the perspective of how the properties of the animal flesh interacted with human bodies, rather than the transmission of a contiguous disease which inhabited both the animal and the human.

Transgression and the human-animal boundary is further reflected in the imagination of late imperial Buddhist pantheons. Among the "five plague envoys" (wuwen shizhe 五瘟使者) depicted in a Yuan-Ming mural in the Buddhist Qinglong Temple in Jishan, Shanxi, only one has a human appearance; while the other four are composite creatures with human bodies and animal heads. ${ }^{55}$ Based on the somewhat damaged mural, the four animal heads can be tentatively identified as that of a tiger, a crow, a chicken, and a horse. The title of this mural, as written on the wall, is "All the Five Plague Envoys" (Wuwen shizhe zhong 五瘟使者眾). Besides this title, there are no other words

\footnotetext{
$5^{1} \quad$ Chen 1939, 271.

$5^{2} \quad$ Kleeman 1994, 185-211; Goossaert 2005, 237-48.

53 Li 2008, 104, 1897.

54 Stanley-Baker 2020.

$55 \quad$ Ping and Su 2001, 18.
} 
in the mural. The image of these plague envoys probably originated from early Chinese beliefs about spirits spreading plague among humans. ${ }^{56}$ In these images we see the crossing or conflating of the human-animal boundary as a generative point for reflecting on the potent power of plagues. While the medical imagination was largely constrained to managing their crossing of human-to-human boundaries through rapid transmission, the religious imagination stretched wider, and considered plagues to also conflate the boundary between the human and the animal.

\section{Conclusion}

The profoundly influential germ theory of disease that spread to Chinese society from the end of the nineteenth century helps to provide a diachronic and noncoherent historical treatment of the human-animal relationship in epidemics in Chinese culture and history. It did not merely function as another explanatory framework for contagion but materialized, visualized, and differentiated between infectious agents, and eventually transformed public understanding of epidemics in twentieth-century China. ${ }^{57}$ Particularly, it underlay the pursuit of more concrete, precise, diverse, and controllable routes of infection between individuals of the same or different species. This gave rise to a new human-animal relationship that brings about intriguing questions such as how the traditional Chinese concept of qi encountered biomedical ideas, and to what extent they, especially in comparison with germ theory, contributed to epidemic control. ${ }^{58}$

We see in the above a number of ways in which the relationships between humans, animals, and disease have been considered through a wide variety of literary genres. From myths and legends to ritual practices, agricultural treatises, and culinary manuals, these snatches of cultural representations enable us to look into Chinese history beyond the recipe texts and materia medica, also referenced here, that make up the standard fare of medical historians. We can see that the human-animal boundary not only inspired the imagination of pantheons but was also borne out of empirical experience of animal husbandry as well as actual zoonotic outbreaks. While no consistent theory of zoonotic transmission captured the imagination of medical writers

$56 \quad$ Cheng and Sun 2020, 110-20.

57 For the transmission of germ theory in modern China, see Andrews 1997, 114-57.

$5^{8}$ Such questions are being researched and still await further exploration. For recent relevant contributions, see Leung 2010, 25-50; Pi 2019. 
over the ages as a central conceptual frame, it was clearly not beyond the limits of imagination, and occurred in incidental references and occasional recipes. Although scholars often talk of a far-reaching "paradigm change" with the coming of biomedicine, some of the reasoning of the premodern world is consistent with modern biological explanations. Disease could be transmitted through eating animal flesh, which either infected bodies directly spreading a common plague across species, through ritual rationales, or through disagreement of the fleshly properties and human physiology. Such ideas and images enable a richer understanding of human-animal interaction, mythology, folk customs, religions, rituals, medical practice, and so on. How they developed out of Chinese culture and affected social responses to epidemics remains a thought-provoking but insufficiently explored topic of historical research.

\section{Acknowledgments}

I am very grateful to the editors and reviewers for providing insightful comments on the original manuscript. I also sincerely thank Tel Aviv University for hosting me as a Zvi Yavetz Fellow.

\section{About the Author}

Di Lu is a Zvi Yavetz Fellow at Tel Aviv University. His research mainly focuses on the circulation of Chinese medical knowledge and medicinal substances and their encounter with European medical sciences and natural history. He has just finished a book-length manuscript on the history of the caterpillar fungus.

\section{Bibliography}

\section{Primary Sources}

Anonymous. 1980 [c. fourth century BCE]. Shanhaijingjiaozhu 山海經校注. Edited by Yuan Ke 袁珂. Shanghai: Shanghai guji chubanshe.

Anonymous. 1985 [Tang dynasty]. “Tangren xie niuyi fang” 唐人寫牛疫方. In Tulufan chutu wenshu 吐魯番出土文書, edited by Tang Changru 唐長臑, book 6, 537-38. Beijing: Wenwu chubanshe.

Anonymous. 1995 [c. first century BCE]. Shennong bencao jing jizhu 神農本草經輯注. Edited by Ma Jixing 馬繼興. Beijing: Renmin weisheng chubanshe. 
Chao Yuanfang 巢元方. 1980 [610]. Zhubing yuanhou lun jiaoshi 諸病源候論校釋. Edited by Nanjing zhongyi xueyuan 南京中醫學院. Beijing: Renmin weisheng chubanshe.

Chen Yuanjing 陳元靚. 1939 [c. 1264]. Suishi guangji 歲時廣記. Changsha: Shangwu yinshuguan.

Dai Tianzhang 戴天章. 1992 [1675]. Guang wenyi lun 廣瘟疫論. Beijing: Renmin weisheng chubanshe.

Fan Ye 范曄. 1965 [c. 445]. Hou Hanshu 後漢書. Beijing: Zhonghua shuju.

Ge Hong 葛洪. 2000 [c. 315]. Zhouhou beiji fang 肘後備急方. Tianjin: Tianjin kexue jishu chubanshe.

Ge Hong 葛洪. 2010 [c. 320]. Shenxian zhuan jiaoshi 神仙傳校釋. Edited by Hu Shouwei 胡守為. Beijing: Zhonghua shuju.

Jia Sixie 賈思劦思. 1982 [c. 544]. Qiminyaoshujiaoshi 齊民要術校釋. Edited by Miao Qiyu 繆啟愉. Beijing: Nongye chubanshe.

Jin Wuxiang 金武祥. 2002 [1881-94]. Suxiang suibi 粟香隨筆. In Xuxiu siku quanshu 續修四庫全書, edited by Gu Tinglong 顧廷龍, book 1184, 1-308. Shanghai: Shanghai guji chubanshe.

Li Chunfeng 李淳風. 2002 [c. tenth century]. Guanxiang wanzhan 觀象玩占. In Xuxiu siku quanshu 續修四庫全書, edited by Gu Tinglong 顧廷龍, book 1049, 153-6o3. Shanghai: Shanghai guji chubanshe.

Li Shi 李石. 2001 [c. 830]. Simu anji ji jiaozhu 司牧安驥集校注. Edited by Zou Jiezheng 鄒介正 and He Wenlong 和文龍. Beijing: Zhongguo nongye chubanshe.

Li Shizhen 李時珍. 2008 [1578]. Bencao gangmu 本草綱目. Edited by Liu Hengru 劉衡 如 and Liu Shanyong 劉山永. Beijing: Huaxia chubanshe.

Li Yiji 李一楫. 1619. Yueling caiqi 月令採奇. Vol. 4. Tokyo: National Archives of Japan.

Ni Zhuo 倪倬. 1956 [1796]. Nongya 農雅. Beijing: Zhonghua shuju.

Ping Feng 品豐 and Su Qing 蘇慶. 2001. Lidai siguan bihua yishu 歷代寺觀壁畫㙯術. Collection 1. Chongqing: Chongqing chubanshe.

Rihuazi 日華子. 2005 [tenth century]. Rihuazi bencao 日華子本草. Edited by Shang Zhijun 尚志鈞. Hefei: Anhui kexue jishu chubanshe.

Shen Defu 沈德符. 1997 [1619]. Wanliyehuo bian 萬曆野獲編. Beijing: Zhonghua Shuju. Sima Qian 司馬遷. 1959 [c. 91 BCE]. Shiji 史記. Beijing: Zhonghua shuju.

Sun Simiao 孫思稃. 1998 [c. 682]. Qianjin yifang jiaoshi 千金翼方校釋. Edited by Li Jingrong 李景榮, Su Li 蘇禮, Ren Juanli 任娟莉, Jiao Zhenlian 焦振廉, and Li Peigen 李培根. Beijing: Renmin weisheng chubanshe.

Wan Quan 萬全. 2002 [1552]. Douzhen gezhi yaolun 痘疹格致要論. In Xuxiu siku quanshu 續修四庫全書, edited by Gu Tinglong 顧廷龍, book 1011, 352-423. Shanghai: Shanghai guji chubanshe.

Wu Qian 吳謙. 1997 [1742]. Yizong jinjian 醫宗金鑒. Beijing: Zhongyi guji chubanshe. 
$\mathrm{Wu}$ Youxing 吳有性. 1990 [1642]. Wenyi lun 溫疫論. Beijing: Renmin weisheng chubanshe.

Zhang Ji 張機. 199o [c. beginning of the third century].Jingui yaolüe jiaozhu 金實要略 校注. Edited by He Ren 何任. Beijing: Renmin weisheng chubanshe.

Zhang Zongfa 張宗法. 1989 [176o]. Sannong ji jiaoshi 三農紀校釋. Edited by Zou Jiezheng 鄒介正, Liu Naizhuang 劉乃壯, Xie Genghua 謝庚華, and Jiang Junmo 江君謨. Beijing: Nongye chubanshe.

Zhu Su 朱橚. 1983 [1406]. Puji fang 普濟方. Book 7. Beijing: Renmin weisheng chubanshe.

Zhuang Zhou 莊周. 1985 [c. fourth century BCE]. Zhuangzi jishi 莊子集釋. Edited by Guo Qingfan 郭慶藩. Beijing: Zhonghua Shuju.

\section{Secondary Sources}

Andrews, Bridie J. 1997. "Tuberculosis and the Assimilation of Germ Theory in China, 1895-1937." Journal of the History of Medicine and Allied Sciences 52, no. 1: 114-57.

Benedict, Carol. 1996. Bubonic Plague in Nineteenth-Century China. Stanford, CA: Stanford University Press.

Cao Shuji 曹樹基 and Li Yushang 李玉尚. 2006. Shuyi, zhanzheng yu heping: Zhongguo de huanjing zhuangkuangyu shehuibianqian (1230-1960) 鼠疫, 戰爭與和平: 中國的 環境狀況與社會變遷 (1230-1960). Jinan: Shandong huabao chubanshe.

Capitanio, Joshua. 2021. "Epidemics and Plague in Premodern Chinese Buddhism." Asian Medicine 16, no. 1: 177-92.

Cheng Botao 程波濤 and Sun Liyuan 孫麗媛. 2020. “Chuantong wenshen tuxiang de shengcheng luoji yu wenhua gongneng” 傳統瘟神圖像的生成邏輯與文化功能. Yuejiang xuekan 4: 110-20.

Colville, Joann L., and David L. Berryhill. 2007. Handbook of Zoonoses: Identification and Prevention. St. Louis, MO: Mosby Elsevier.

Deng Tietao 鄧鐵濤. 2006. Zhongguo fangyi shi 中國防疫史. Nanning: Guangxi kexue jishu chubanshe.

Diamond, Jared. 1999. Guns, Germs, and Steel: The Fates of Human Societies. New York: W. W. Norton \& Company.

Echenberg, Myron. 2002. "Pestis Redux: The Initial Years of the Third Bubonic Plague Pandemic, 1894-1901." Journal of World History 13, no. 2: 429-49.

Feng Lanlan 馮蘭蘭 and Feng Hongqian 馮洪錢. 2003. "Renshou gonghuan tanjubing gujin kao 人獸共患炭疽病古今考.” Nongye kaogu 3: 291-94.

Gong Shengsheng 竟勝生. 2003. "Zhongguo yizai de shikong fenbu bianqian guilü" 中國疫災的時空分佈變遷規律. Dilixuebao 58, no. 6: 870-78.

Gong Shengsheng 龔勝生. 2019. Zhongguo sanqian nian yizai shiliao huibian 中國三千 年疫災史料彙編. Jinan: Qilu shushe. 
Gong Shengsheng 龔勝生, Xie Haichao 謝海超, and Chen Fahu 陳發虎. 2020. “2200 nian lai woguo wenyi zaihai de shikong bianhua jiqi yu shengcun huanjing de guanxi”2200 年來我國瘟疫災害的時空變化及其與生存環境的關係. Zhongguo kexue: Diqiu kexue 5o, no. 5: 719-22.

Goossaert, Vincent. 2005. "The Beef Taboo and the Sacrificial Structure of Late Imperial Chinese Society." In Of Tripod and Palate: Food, Politics, and Religion in Traditional China, edited by Roel Sterckx, 237-48. New York: Palgrave Macmillan.

Gross, Miriam. 2016. Farewell to the God of Plague: Chairman Mao's Campaign to Deworm China. Oakland: University of California Press.

Han Yi 韓毅. 2015. Songdai wenyi de liuxing yu fangzhi 宋代瘟疫的流行與防治. Beijing: Shangwu yinshuguan.

Hanson, Marta. 2011. Speaking of Epidemics in Chinese Medicine: Disease and the Geographic Imagination in Late Imperial China. London: Routledge.

Hanson, Marta. Forthcoming. "Late Imperial Epidemiology." In Routledge Handbook of Chinese Medicine, edited by Vivienne Lo and Michael Stanley-Baker. London: Routledge.

Iijima Wataru 飯島涉. 2000. Pesuto to kindai Chūgoku: Eisei no “seidoka" to shakai henyō ペストと近代中国: 衛生の「制度化」と社会变容. Tokyo: Kenbun shuppan.

Imura Kōzen 井村哮全. 1936-1937. “Chihōshi ni kisai seraretaru shina ekirei ryakukō" 地方志に記載せられたる支那疫㾖略考. Chūgai iji shimpō (1232-39): 263-275, 316$325,366-376,414-422,459-467,505-507,550-555,30-39$.

Jiao Runming 焦潤明. 2011. Qingmo Dongbei sansheng shuyi zainan ji fangyi cuoshi yanjiu 清末東北三省鼠疫災難及防疫措施研究. Beijing: Beijing shifan daxue chubanshe.

Kleeman, Terry F. 1994. "Licentious Cults and Bloody Victuals: Sacrifice, Reciprocity, and Violence in Traditional China." Asia Major 7, no. 1: 185-211.

Lai Wen 賴文 and Li Yongchen 李永宸. 1999. “1894 nian Guangzhou shuyi kao.” 1894 年 廣州鼠疫考. Zhonghua yishi zazhi 29, no. 4: 207-10.

Lai Wen 賴文 and Li Yongchen 李永宸. 2004. Lingnan wenyi shi 嶺南瘟疫史. Guangzhou: Guangdong renmin chubanshe.

Leung, Angela Ki Che. 20o9. Leprosy in China: A History. New York: Columbia University Press.

Leung, Angela Ki Che. 2010. "The Evolution of the Idea of Chuanran Contagion in Imperial China." In Health and Hygiene in Chinese East Asia: Policies and Publics in the Long Twentieth Century, edited by Angela Ki Che Leung and Charlotte Furth, 25-5o. Durham, NC: Duke University Press.

Li Honghe 李洪河. 2007. Xin Zhongguo de yibing liuxing yu shehui yingdui (1949-1959) 新中國的疫病流行與社會應對 (1949-1959). Beijing: Zhonggong dangshi chubanshe.

Li Wenbo 李文波. 2004. Zhongguo chuanranbing shiliao 中國傳染病史料. Beijing: Huaxue gongye chubanshe. 
Liu Huizhen 劉暉楨. 2005. “Renchu gonghuan bing xiaokao: Tanju” 人畜共患病小考: 炭疽. In Zhongyiyaofazhanyurenleijiankang 中醫藥發展與人類健康, edited by Cao Hongxin 曹洪欣 and Li Huairong 李懷榮, 344-48. Beijing: Zhongyi guji chubanshe.

Liu, Yan. 2015a. "Poisonous Medicine in Ancient China." In History of Toxicology and Environmental Health: Toxicology in Antiquity, Vol. 2, edited by Philip Wexler, 89-97. Amsterdam: Academic Press.

Liu, Yan. 2015b. "Toxic Cures: Poisons and Medicines in Medieval China." PhD diss., Harvard University.

Mackenzie, John S., and David Williams. 2020. "Zoonoses." Microbiology Australia 41, no. $1: 3-5$.

Messenger, Ali M., Amber N. Barnes, and Gregory C. Gray. 2014. "Reverse Zoonotic Disease Transmission (Zooanthroponosis): A Systematic Review of SeldomDocumented Human Biological Threats to Animals." PLoS ONE 9, no. 2: e89o55.

Niu Jiafan 牛家藩. 1989. “Shilun Qingdai shouyi bencaoxue de fazhan tese” 試論清代獸 醫本草學的發展特色. Zhongguo nongshi 4: 82-84.

Nong Wanju 農萬菊 and Chen Haiyun 陳海雲. 1996. Guangxi xumu shi 廣西畜牧史. Nanning: Guangxi renmin chubanshe.

Pi Guoli 皮國立. 2019.Jindai Zhongxiyi de boyi:Zhongyi kangjun shi 近代中西醫的博弈: 中醫抗菌史. Beijing: Zhonghua shuju.

Stanley-Baker, Michael. 2020. "Daoism and Disease in China and Diaspora." Fieldsights (blog of the Society for Cultural Anthropology), "Hotspots" section, June 23, 2020. https://culanth.org/fieldsights/daoism-and-disease-in-china-and-diaspora.

Sterckx, Roel. 2002. Animal and the Daemon in Early China. Albany: State University of New York Press.

von Glahn, Richard. 2004. The Sinister Way: The Divine and the Demonic in Chinese Religious Culture. Berkeley: University of California Press.

Wang Yuhu 王毓瑚. 1958. Zhongguo xumushi ziliao 中國畜牧史資料. Beijing: Kexue chubanshe.

Watt, John R. 2013. Saving Lives in Wartime China: How Medical Reformers Built Modern Healthcare Systems amid War and Epidemics, 1928-1945. Leiden: Brill.

Xie Chengxia 謝成俠. 1985. Zhongguo yang niuyang shi 中國養牛羊史. Beijing: Nongye chubanshe.

Xie, Guihua. 2005. "Han Bamboo and Wooden Medical Records Discovered in Military Sites from the North-Western Frontier Regions." In Medieval Chinese Medicine: The Dunhuang Medical Manuscripts, edited by Vivienne Lo and Christopher Cullen, 78-106. London: RoutledgeCurzon.

Yu Xinzhong 余新忠. 2003. Qingdai jiangnan de wenyi yu shehui: Yixiang yiliao shehuishi de yanjiu 清代江南的瘟疫與社會: 一項醫療社會史的研究. Beijing: Zhongguo renmin daxue chubanshe.

Yu Xinzhong 余新忠. 2016. Qingdai weisheng fangyijizhi jiqi jindai yanbian 清代衛生防 疫機制及其近代演變. Beijing: Beijing shifan daxue chubanshe. 
Zhang Jianguang 張劍光. 1998. Sanqian nian yiqing 三千年疫情. Nanchang: Jiangxi gaoxiao chubanshe.

Zhang Taishan 張泰山. 2008. Minguo shiqi de chuanranbing yu shehui: Yi chuanranbing fangzhiyu gonggong weisheng jianshe wei zhongxin 民國時期的傳染病與社會: 以傳 染病防治與公共衛生建設為中心. Beijing: Shehui kexue wenxian chubanshe.

Zhang Zhibin 張志斌. 2007. Zhongguo gudai yibing liuxing nianbiao 中國古代疫病流 行年表. Fuzhou: Fujian kexue jishu chubanshe.

Zhou Qiong 周瓊. 2007. Qingdai Yunnan zhangqi yu shengtai bianqian yanjiu 清代雲南 瘴氣與生態變遷研究. Beijing: Zhongguo shehui kexue chubanshe.

Zhou, Xun. 2020. The People's Health: Health Intervention and Delivery in Mao's China, 1949-1983. Montreal: McGill-Queen's University Press.

Zou Jiezheng 鄒介正, Wang Mingnong 王銘農, Niu Jiapan 牛家藩, He Wenlong 和文 龍, and Li Qun 李群. 1994. Zhongguo gudai xumu shouyi shi 中國古代畜牧獸醫史. Beijing: Zhongguo nongye keji chubanshe. 